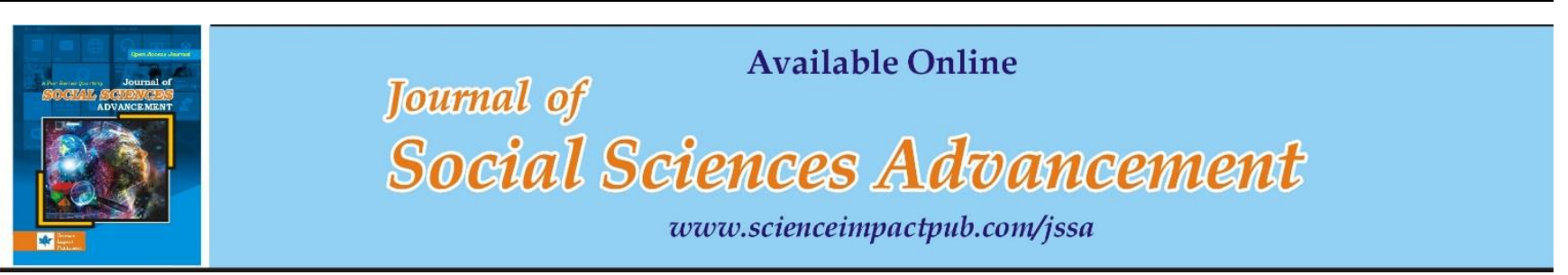

\title{
IMPACT OF HUMAN CAPITAL ON ECONOMIC GROWTH: A CASE STUDY OF PAKISTAN
}

\author{
Raheela khatoon $^{1 *}$, Iqbal Javed ${ }^{2}$ and Muhammad Munawar Hayat ${ }^{3}$ \\ ${ }_{1}^{1}$ Akhuwat College for Women Chakwal, Pakistan \\ 2Department of Economics, University of Lahore, Sargodha Campus, Sargodha, Pakistan \\ ${ }^{3}$ School Education Department, Government of Punjab, Pakistan
}

\begin{abstract}
A country is prosperous if it has efficient development programs. Human capital contains resources like education, health, training, skills etc. For economic progress these qualities are very vital. Basic objective of this research is to explain the impact of human capital on growth and development of economics sector of the Pakistan. Because today in the developing countries, human development and growth has becomes the burning issues. To analyse the association between human capital and economic growth, used GDP as a dependent variable. This study further use Human development index as independent variable. Proxy of human development index consist of education index, health, fertility, infant mortality, life expectancy and sanitation. Our focus will be more on the education. Time series data for the years 1990-2019 were used. ARDL model was used by incorporating the human capital formation with other explanatory variables. The findings shows that the human capital has positive and significant impact on growth and the negative influence on the population and infant mortality rate.
\end{abstract}

\begin{tabular}{ll}
\hline Keywords: Human capital; economic growth; effect; human development index; Pakistan \\
\hline Corresponding Author: Raheela Khatoon, Email: raheelaacw@gmail.com \\
(c) The Author(s) 2021.
\end{tabular}

\section{INTRODUCTION}

A country is prosperous if it has efficient development programs, economy mobilizing strategies including mobilization of money and human resource leading to economic growth. All this is accomplished with the assistance of budgetary support, however in the case of developing countries this seems challenging as they have to fill in the expenditures and then deficits. Along with these materials things for better economic development and growth human resource is necessary, to reduce poverty, increase human development and better living standards. Thus, for development and growth of human capital education and health are major factors as different theories has proved it. Basic goals of each developing country is to attain the high level of economic growth. But these countries face many problems in order to achieve these goals. The low level of labor productivity, low capital stock, low production capacity and low level of savings and investments are the main characteristics of these countries. Or these are the main hurdle to achieve the high growth like developed countries. The initiative of millennium development goals (MDGs) by the United Nations truly enhanced the development among developing countries. This program emphasized on the reduced poverty, hunger, attainment of primary education, increased life expectancy, better empowerment, health, global partnership and overall sustainability.

Asghar et al., (2012) assessed the significance of human capital on growth rate. This study applied annual data to investigate the stochastic properties of the variable by using Ng-Perron and ADF. The technique used was Cointegration that's showed long term association. The results indicate significant linked among growth of economics and human capital.

Haider et al., (2012) explained the relationship between economic growth and infrastructure growth of Pakistan over the time period of 1972 to 2009 and GDP is explained variable, while Gross Fixed Capital Formation (GFCF), Health Expenditure (HE) and Total Electricity (TE) used as proxy for infrastructure. Johensen Cointegration technique has been used and results displays that there is no long run association exists. Then Ordinary Least Square (OLS) used to discover short- run affiliation between variables and outcomes indicate that economic growth of Pakistan has significantly influenced by infrastructure factors.

Hanushek, (2013) examined the effect of human capital on economic growth. Current research has emphasized the importance of cognitive skills for economic growth. The result shows that developing countries need to enhance the quality of education in that way they can compete the developed countries. Without refining school quality, developing countries would not gain economic progress. 
In Ethiopia Kidanemariam Gidey Gebrehiwot (2014) tried to check the relationship between economic growth and human capital in the long run as well as in the short run. For results estimation used Error Correction Model and cointegration. Results shows that long run relationship between economic growth and human capital exists. And in results long run model explained that health of human whose treated as capital is main factor of real GDP.

Amir and Khan (2015) concluded that Health plays substantial role in the progress of human capital. Cobb Douglas Production function used in this research. Time series data has been used for estimation. Johnson's cointegration, vector error correction method, error correction method and Granger Causality techniques were used for the estimation of results. Results shows that economic growth have positive relation with human capital.

For Pakistan, (Shahzad, 2015) explore the importance of human capital formation for the growth of the economy. The OLS method is employed. Variables which are positively and significantly effect on GDP are Education Enrollment Index, Gross fix capital formation and investment growth rate. There are negative but significant relationship between Infant Mortality Rate and consumer price index with GDP. These finding revealed that both health and education sector should be improved to maintain the economic growth of Pakistan.

Similarly, in Pakistan Ahad Hassan Afridi (2016) examined the association between human capital and economic development. The result indicated that the part of human capital is encouraging progress in Pakistan. Furthermore, result suggests that the two main sectors which need extensive attention are education and health.

In Nigeria P. A. Adeyemi1 and A. J. Ogunsola (2016) analyze the relationship between growth of the economy and human capital. In this research for estimation the time series data has been used. ARDL Co-integration method employed to evaluate the link between the variables. Estimation of results revealed that in long run there is positive but insignificant association among, life expectancy rate, gross capital formation, public expenditure on education, secondary school enrolment and economic growth. The results also describe that there is negative long-run relationship between public expenditure on health, primary, tertiary school enrolment and economic growth.

Bahadur \& Chhetri (2017) investigated the relationship between economic growth and human capital in developing countries. Determinants of economic growth are gross domestic product, per capita income, death rate, life expectancy at birth, birth rate, population, human capital age population, literacy rate and investment in technology. He used Solow model to check the technological progress in the country. Results shows that determinant of economic growth have positive relation with GDP.

According to Syed Mohsin Kazmi, Kazim Ali and Ghamze Ali (2017) the variables like school enrolments, life expectancy, health, knowledge, and skills are known as human capital. The long run findings of Johansen cointegration revealed that there is a association among the growth of the economy and human capital. Furthermore, the main focus is more spending on education which is useful for the growth of the country. Similarly, Ejiro U. Osiobe (2019) tried to check the association among the growth of the economy and human capital.

A study done by P. Eko Prasetyo (2020) described the new growth theory. The economic growth can be achieved through technological changes as the accumulation of human capital. The basic aim of the research is to enlighten new growth theory through the empirical data. The paper shows that human capital is the key and leading contribution to boost the regional micro and macro-economic growths. For South Africa Collins C. Ngwakwe (2020) analyze the mutually dependency between economic growth and human development. This study revealed that the theory of economic wellbeing (which measures the economic growth) by containing the welfare of all and not only on GDP. The vector auto-regression and the Granger causality Wald tests are employed. The interesting finding of this study revealed that human development are health or life expectancy, standard of living or GNI and education.

For Pakistan, the main aim of the whole analysis is to empirically find the impact of human capital on economic growth. The study try to explore that the human capital has positive or the negative impact on the economic growth. We have used the time series data by covering the period 1990-2019 to explore the association among the growth of the economy and Human Capital. ADF statistic has been applied to find the stationary of the variables. To check the short and long run relationship between variables the ARDL method are used. Furthermore, to check the stability of the model Bound test and some stability test has been used. The CUSUM and (CUSUMSQ) were performed in this study.

\section{METHODOLOGY}

For Pakistan the time series data is taken over the year 1990-2019. The main goal of this study is to examine the relationship between Human Capital and economic growth. The data is attained from the World Bank Indicators and Pakistan and Economic Survey. 
$\mathrm{GDP}=\beta 0+\beta 1(\mathrm{LGCF})+\beta 2(\mathrm{LHDI})+\beta 3(\mathrm{LIGR}) \beta 4(\mathrm{LEAB})+\beta 5(\mathrm{LPOP})+\beta 6(\mathrm{LIMR}$

LGDP= Log of Gross Domestic Product

LGCF= Log of Gross Capital Formation

LHDI= Log of Human Development Index

LIGR = Log of Investment Growth Rate

$\mathrm{LEAB}=\mathrm{Log}$ of Life expectancy at birth

LPOP= Log of Population

LIMR= Log of Infant Mortality Rate

GDP computes the overall production of goods and services in a country in a specific year. It is a measure of economic growth of a country. In this study, GDP used as a dependent variable. GCF signifies the factors of production. It is also known as fixed capital formation. Human Development index used as a proxy for Education. Life expectancy at birth and infant mortality rate used as a proxy of health. Investment growth rate shows the overall investment which effect the growth of the country.

The ARDL approach is beneficial for time series data for estimating long-run relationships from short-run dynamics. Pesaran et al. (2001) recognized that ARDL is more flexible method for econometric analysis. If the series is $1(2)$ we can't apply this approach due to order integration which cause invalidates critical values and F-statistics. (Ali et al. 2016) explained that endogeneity problem is eradicated due to appropriate lag selection criteria. After the modification in the short run and the long run equilibrium achieved through the error correction mechanism (ECM).

Rahman and Kashem (2017) concluded that the execution of ARDL Model is not complicated but relatively straight forward, it relays only a single regression equation as compared to other Models which depends on system of equations. In this study ARDL Methodology is applied to observe the short run as well as long run relationship existing between the variables. Diagnostic Test applied to check stability of the Model. Heteroscedasticity, Auto Correlation, Ramsey RESET test for Model specification, Jarque-Bera Normality Test, CUSUM and CUSUMSQ has performed.

\section{Unit Root Test}

We used Unit root test to check the Stationary of the variables.

Table 1. Result of ADF test.

\begin{tabular}{lccccc}
\hline \multirow{2}{*}{ Variables } & \multicolumn{2}{c}{ At level ADF Statistics } & \multicolumn{3}{c}{ At First Difference ADF Statistics } \\
\cline { 2 - 6 } & Intercept & Trend, Intercept & Intercept & Trend, Intercept & Integration Order \\
\hline LGDP & -0.28779 & -2.246322 & $5.650101^{*}$ & $-5.552177^{*}$ & $1(1)$ \\
LGCF & -0.301032 & -2.311318 & $5.526682^{*}$ & $-5.422677^{* * *}$ & $1(1)$ \\
LHDI & -1.265705 & -0.298692 & $3.130416^{* *}$ & $-3.25164^{*}$ & $1(1)$ \\
LIGR & -4.366818 & $-4.264516^{*}$ & & - & $1(0)$ \\
LEAB & -2.205983 & -1.345029 & 0.581946 & $-3.662352^{* *}$ & $1(1)$ \\
LPOP & -0.736221 & $-6.527177^{*}$ & - & - & $1(0)$ \\
LIMR & 1.425258 & $-7.371077^{*}$ & - & - & $1(0)$ \\
\hline
\end{tabular}

Table 1 shows the results of ADF Statistics. The dependent variable GDP is stationary at 1st difference while the other explanatory variables Gross Capital Formation, Human Development Index, Life expectancy at birth are also stationary at 1st difference. Investment Growth Rate, Population and Infant Mortality Rate are stationary at Level.

Table 2. Lag selection

\begin{tabular}{lllllll}
\hline Lag & LogL & LR & FPE & AIC & SC & HQ \\
\hline 0 & 467.6042 & NA & $3.59 \mathrm{E}-24$ & -34.11883 & -33.78287 & -34.01893 \\
1 & 819.9725 & 495.9258 & $7.10 \mathrm{E}-34$ & -56.59055 & -53.90289 & -55.79137 \\
2 & 989.814 & $150.9703^{*}$ & $2.18 \mathrm{e}-37^{*}$ & $-65.54178^{*}$ & $-60.50241^{*}$ & $-64.04331^{*}$ \\
\hline
\end{tabular}

Table 2 suggest the selection of lags by AIC criteria. Here the endogenous variables are LGDP, LGCF, LHDI, LIGR, LEAB, LPOP, LIMR while the exogenous variable is C. Akaike info criterion suggest that the optimal Lag length is 3. 
Table 3. Short Run ARDL (Auto-regressive Distributed Lag) Model.

\begin{tabular}{l|l|l|l|l}
\hline Variables & Coefficients & Standard Error & T-Statistic & Probability.* \\
\hline LGDP(-1) & -0.509114 & 0.189394 & -2.68812 & 0.0169 \\
LGCF & 13.102 & 1.100172 & 11.90905 & 0.0000 \\
LHDI & 1.706581 & 0.66283 & 2.574689 & 0.0211 \\
LIGR & 0.022222 & 0.006135 & 3.622264 & 0.0025 \\
LEAB & 146.1349 & 24.74494 & 5.905648 & 0.0000 \\
LPOP & -5.803128 & 1.191652 & -4.869819 & 0.0002 \\
LIMR & -2.411099 & 1.002581 & -2.404893 & 0.0295 \\
C & -49.97653 & 28.36163 & -1.762118 & 0.0984 \\
R-squared & 0.999646 & & \\
Adjusted R-squared & 0.999386 & & \\
Prob(F-statistic) & 0.0000 & & \\
Akaike info criterion & -5.19172 & & \\
Durbin-Watson stat & 2.000548 & & \\
\hline
\end{tabular}

These are the results of short run ARDL model as shown in Table 3. The R- squared and Adjusted R-squared value is 0.99 which is superior, indicates the model is best fit. The Prob (F-statistic) is 0.00 percent shows the significance of the whole model. Akaike info criteria has been used in this model. All the variables like GDP Prob value (0.0169), LGCF Prob value (0.0000) LHDI Prob (0.0211), LIGR Prob value (0.0222), LEAB Prob value (0.0000), LPOP Prob value (0.0002), LIMR Prob value (0.0295) Constant Prob value (0.0984) are significant. The Co-efficient for LGCF is (13.10200) which means that if LGCF increase by 1 percent then the GDP will increase by 13.10 percent in the short run. The Co- efficient for LHDI is (1.706581) which means that if LHDI increase by 1 percent then the GDP will increase by 1.7 Percent. LIGR and LEAB have a positive relationship with GDP. While one percent increase in POP will decrease the GDP at $5.8 \%$. Result shows that 1 percent rise in LIMR will decline the GDP at 2.4 percent in the short run. So it indicates that population and infant mortality rate have negative relationship with GDP.

Table 4. ARDL Co-integrating Long Run Model (Long Run Coefficients).

\begin{tabular}{lllll}
\hline Variable & Coefficient & Std. Error & t-Statistic & Prob. \\
\hline LGCF & 11.12792 & 0.652024 & 17.06673 & 0.0000 \\
LHDI & 1.025671 & 0.385038 & 2.663815 & 0.0177 \\
LIGR & 0.024171 & 0.006907 & 3.499279 & 0.0032 \\
LEAB & 22.32738 & 2.285612 & 9.768667 & 0.0000 \\
LPOP & -3.48774 & 0.438688 & -7.95037 & 0.0000 \\
LIMR & -1.44909 & 0.555341 & -2.60937 & 0.0197 \\
C & -30.0364 & 16.54562 & -1.81537 & 0.0895 \\
\hline
\end{tabular}

All the variables are significant in the long run as shown ion Table 4. If Gross Capital Formulation increase by 1 percent, the GDP will increase by 11 percent. Human development Index increases by 1 percent, the GDP will increase by 1.02 percent. Investment Growth Rate and Life expectancy at birth have a positive relationship with GDP. While 1 percent increase in Population will decrease the GDP at 3.48 percent. Infant Mortality Rate has a negative relationship with GDP. The CointEq is the ECM value i-e (-1.663867) which indicates that dependent variable GDP is converging towards equilibrium. It is also called the speed of correction. Every year the dependent variable is converging 1.66 percent towards equilibrium due to the changes in other variables. The ECM value is also significant which show the best results of the Model.

Table 5. Diagnostic test.

\begin{tabular}{|c|c|c|c|c|c|}
\hline Issues & Diagnostic Test & Hypothesis & $\begin{array}{l}\text { F- } \\
\text { Statistic }\end{array}$ & $\begin{array}{l}\text { Prob- } \\
\text { Value }\end{array}$ & Decision \\
\hline $\begin{array}{l}\text { Heterosced } \\
\text { asticity }\end{array}$ & $\begin{array}{l}\text { Heteroscedasticity Test } \\
\text { (Breusch Pagan Godfrey ) }\end{array}$ & $\begin{array}{l}\mathrm{H} 0=\text { residuary are homoscedastic } \mathrm{H} 1= \\
\text { residuary are not homoscedastic }\end{array}$ & 0.6422 & 0.6331 & $\begin{array}{l}\text { Accept the null } \\
\text { Hypothesis }\end{array}$ \\
\hline $\begin{array}{l}\text { Auto- } \\
\text { correlation }\end{array}$ & LM Test & $\begin{array}{l}\mathrm{H} 0=\text { no autocorrelation occur } \\
\mathrm{H} 1=\text { autocorrelation occur }\end{array}$ & 0.7224 & 0.3763 & $\begin{array}{l}\text { Accept the null } \\
\text { Hypothesis }\end{array}$ \\
\hline $\begin{array}{l}\text { Specificatio } \\
\text { n Problem }\end{array}$ & Ramsey RESET Test & $\begin{array}{l}\mathrm{H} 0=\text { Accurate description of the model } \\
\mathrm{H} 1=\text { inaccurate description of the } \\
\text { model }\end{array}$ & 5.1191 & 0.071 & $\begin{array}{l}\text { Accept the null } \\
\text { Hypothesis }\end{array}$ \\
\hline $\begin{array}{l}\text { Residuals } \\
\text { Normality }\end{array}$ & Jarque-Bera Normality Test & $\begin{array}{l}\mathrm{H} 0=\text { Residuals are normally distributed } \\
\mathrm{H} 1=\text { Residuals are not normally } \\
\text { distributed }\end{array}$ & 4.8144 & 0.091 & $\begin{array}{l}\text { Accept the null } \\
\text { Hypothesis }\end{array}$ \\
\hline
\end{tabular}


To check the Stability of the model we used cumulative sum (CUSUM) and the cumulative sum of squares (CUSUMSQ) of the residual as sown in Figure 1. The statistics disclose that the red lines remain outside the blue line. So (CUSUM) and CUSUMSQ) shows that the model properly quantified and steady in the long run and in the short run.
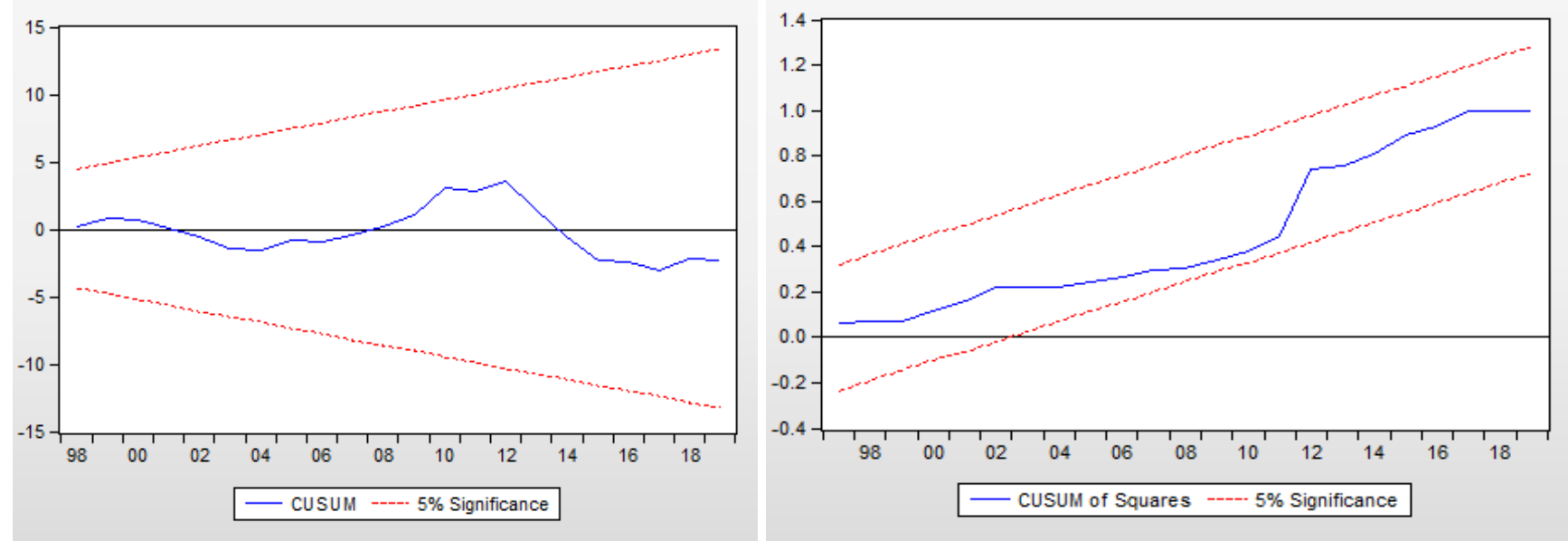

Figure 1. CUSUM

\section{CONCLUSION AND POLICY RECOMMENDATION}

The finding of this study indicated that, long run association between Economic growth, Gross Capital Formation, Human Development Index, Investment Growth Rate, Life Expectancy at birth, Population and Infant Mortality Rate. For Pakistan the time series data for the period of 1990-2019 and the allegation of production function Cobb- Douglas to consider the role of human capital in the economic growth of the country. The Neoclassical Growth Theory and the Endogenous Growth Theory suggest that the human capital is the important element of production. The rise in gross capital results to increase in the investment which accelerate the production. This study suggests that the investment in human can speed up productivity. Furthermore, the findings revealed a strong mutual association among the growth of the economy and human capital. Moreover, current study strongly supports more funds from GDP to divert in education and health sector investment to achieve sustainable economic growth which is useful for the development of the country.

Likewise, the study concluded that human capital is essential for economic growth; as increase in human capital will also increases the physical capital. In a country with rise in the stock of human capital attracts more investment as a result production process enhance (GDP). Good health have a positive long-run effect on economic growth. As good health helps to accelerate the life expectancy rate and human capital that leads to increase the economic growth as a whole. Government should take steps for creating new jobs opportunities which will reduce the population burden from the economy. Masses of the country will be prosperous and the economy will grow. The Government should take steps to encourage the investment because some people scared and could not take risks to invest money. If investment opportunities increase, then definitely it will be positive impact on economic growth. Cognitive skills will be helpful to gain financial stability.

\section{REFERENCES}

Akram, Z., A. Shahzad and Z.Bibi. 2015. Factors affecting low enrollment and high dropout rate at primary school in Khohat division. APP. Sci Report. 11(2): 83-86.

Adeyemi, P. A., \& Ogunsola, A. J. (2016). The impact of human capital development on economic growth in Nigeria: ARDL approach. IOSR Journal of Humanities and Social Science, 21(3), 1-7.

Afridi, A. H. (2016). Human Capital and Economic Growth of Pakistan. Business \& Economic Review, 8(1), 77-86. https://doi.org/10.22547/ber/8.1.5

Ali, S., Sharif Chaudhry, I., \& Farooq, F. (2012). Human Capital Formation and Economic Growth in Pakistan. Pakistan Journal of Social Sciences (PJSS), 32(1).

Asghar, N., Awan, A., \& Rehman, H. ur. (2012). Human Capital and Economic Growth in Pakistan: A Cointegration and Causality Analysis. International Journal of Economics and Finance, 4(4), 135-147. https://doi.org/10.5539/ijef.v4n4p135

Bahadur, S., \& Chhetri, K. (2017). The Relationship between Human Capital and Economic Growth in Developing Countries A Study and Analysis on Developing Countries. Sodertorns Hogskola Stockholm, 1-79. http://sh.divaportal.org/smash/get/diva2:1177718/FULLTEXT02.pdf

Gebrehiwot, K. G. (2014). The impact of human capital development on economic growth in Ethiopia: Evidence from ARDL Approach to Co-Integration. American Journal of Trade and Policy, 1(3), 127-136. 
Haider, S. Z., Amjad, M. U., Ullah, S., \& Naveed, T. A. (2012). Role of Infrastructure in Economic Growth: A Case Study of Pakistan. Asian Development Studies, 1(1), 13-21.

Hanushek, E. A. (2013). Economic growth in developing countries: The role of human capital. Economics of Education Review, 37, 204-212. https://doi.org/10.1016/i.econedurev.2013.04.005

Hina Amir, Muhammad Khan (2015) Long Run Relationship between Human Capital and Economic Growth in Pakistan: A Time Series Analysis.

Khan, Z., Ali, A., \& Ali, S. (2016). Impact of devaluation on balance of trade: A case study of Pakistan economy. Asian Journal of Economic Modelling, 4(2), 90-94.

Ngwakwe, C. C. (2020). EuroEconomica Measuring the Interdependence between Economic Growth and Human Development in South Africa EuroEconomica. 2(2).

Osiobe, E. U. (2019). A Literature Review of Human Capital and Economic Growth. Business and Economic Research, 9(4), 179. https://doi.org/10.5296/ber.v9i4.15624

Pesaran, M.H., Shin, Y., \& Smith, R.J. (2001). Bounds testing approaches t the analysis of level relationships. Journal of Applied Econometrics, 16, 289-326.

Prasetyo, P. E. (2020). Human capital as the main determinant of regional economic growth. International Journal of Advanced Science and Technology, 29(3), 6261-6267.

Rahman, M. M., \& Kashem, M. A. (2017). Carbon emissions, energy consumption and industrial growth in Bangladesh: Empirical evidence from ARDL cointegration and Granger causality analysis. Energy Policy, 110(October), 600608. https://doi.org/10.1016/j.enpol.2017.09.006

Shahzad, F. (2015). Role of human capital on economic growth: A case study of Pakistan. International Journal of Accounting and Economics Studies, 3(1), 20. https://doi.org/10.14419/ijaes.v3i1.4120

Syed, M. K., Kazim, A., \& Ghamze, A. (2017). Impact of Human capital on Economic Growth: Evidence from Pakistan A publication of the Sustainable Development Policy Institute (SDPI). 12. www.sdpi.org

Publisher's note: Science Impact Publishers remain neutral with regard to jurisdictional claims in published maps and institutional affiliations.

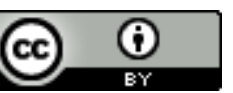

Open Access This article is licensed under a Creative Commons Attribution 4.0 International License, which permits use, sharing, adaptation, distribution and reproduction in any medium or format, as long as you give appropriate credit to the original author(s) and the source, provide a link to the Creative Commons license and indicate if changes were made. The images or other third-party material in this article are included in the article's Creative Commons license, unless indicated otherwise in a credit line to the material. If material is not included in the article's Creative Commons license and your intended use is not permitted by statutory regulation or exceeds the permitted use, you will need to obtain permission directly from the copyright holder. To view a copy of this license, visit https://creativecommons.org/licenses/by/4.0/.

(C) The Author(s) 2021 